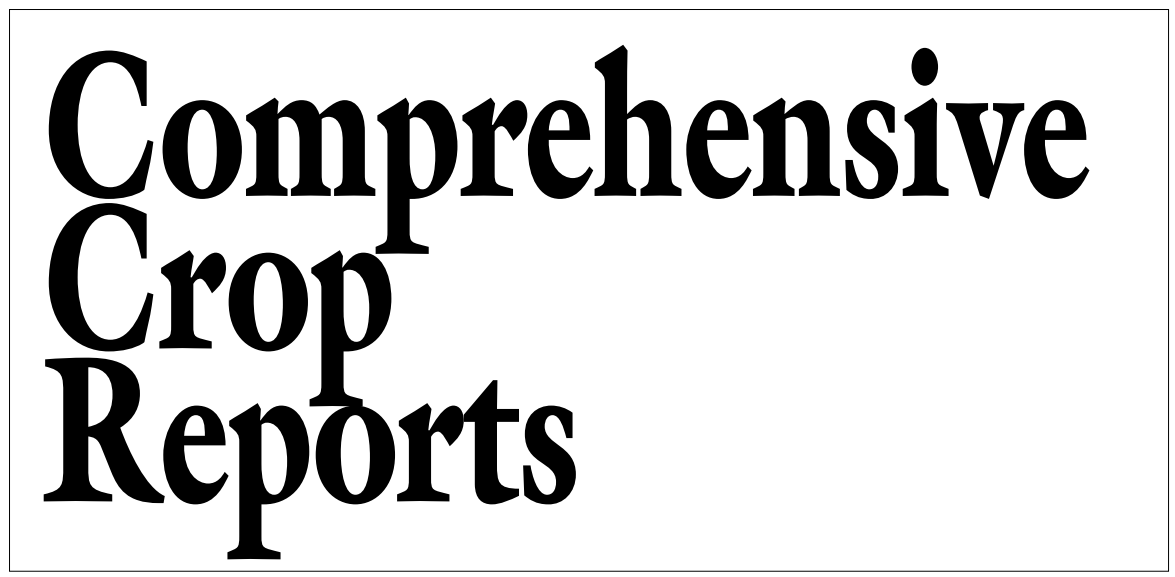

\section{Culture and Use of Black Locust}

\author{
Tom DeGomez ${ }^{1}$ and \\ Michael R. Wagner ${ }^{2}$
}

Additional Index wORds. bristly locust, clammy locust, new mexican locust, Robinia hispida, Robinia

neomexicana, Robinia pseudoacacia, Robinia viscosa

Summary. Robinia L. (locust) species are among the most widely planted tree species in the world because they are ornamentally attractive, drought tolerant, fast growing, fix nitrogen, have very hard durable wood, and are adaptable to many sites and climates. Recent taxonomic analysis indicates there are four species, black locust $(R$. pseudoacacia L.); bristly locust ( $R$. bispida L.); clammy locust (R. viscosa Vent.); and new mexican locust ( $R$. neomexicana A. Gray). All four species originate in the southern United States and northern Mexico. Many horticultural cultivars are available. Locusts are tolerant of a wide range of soil types so long as there is good drainage, adequate moisture, and it is not very clayey. The environmental tolerance of locust makes it an excellent candidate for horticultural uses and for future breeding and selection to enhance its many desirable traits. It is easy to propagate via seed, root cuttings, soft- or hardwood

The cost of publishing this paper was defrayed in part by the payment of page charges. Under postal regulations, this paper therefore must be hereby marked advertisement solely to indicate this fact.

${ }^{1}$ University of Arizona Cooperative Extension, 2304 N. 3rd Strret, Flagstaff, AZ 86004

${ }^{2}$ School of Forestry, Northern Arizona University, Box 15018 Flagstaff, AZ 86011. cuttings, budding/grafting, or tissue culture. Locust has indeterminate growth. Spacing of plants in plantations is critical for the production of multiple products including high value timber. Locust is known for its ability to withstand drought conditions however at the cost of leaf shedding. Black locust contributes high levels of nitrogen to the soil from nitrogen fixing bacterial symbiosis. The major drawback to large-scale production of black locust in its native range is the damage that occurs from the locust borer (Megacyllene robiniae Forster). When planted outside the range of the locust borer it can be grown successfully as landscape specimen trees and as trees large enough for lumber production when varieties with straight trunks are grown. Damage from locust leaf miner (Odontata dorsalis Thunberg) can greatly detract from the trees ornamental qualities. Its most common use is as a site reclamation species. The tree is also used in honey production. The wood is highly decay resistant and is greatly valued for poles and posts. The wood is extremely hard and easy to work making it highly desirable for many construction uses.

$R$ obinia is a cold temperate arborescent genus that has its center of origin in the deciduous forests of the eastern and southwestern United States (Graham, 1987; Lavin, 1987). There is great interest in black locust in plantation and restoration forestry because the species grows quickly, fixes nitrogen, stabilizes soils, and produces wood that is extremely durable (Hanover, 1992). Locust is grown rarely in plantations in the eastern United States but is used widely on mine reclamation sites. In Europe and Asia it is used commonly in plantations and as a reclamation species. Black locust is increasingly grown as a horticultural species (Nowak and Syndor, 1992) and numerous cultivars have been described (ArborVillage, 1997; Carlton; 1997; Keresztesi, 1988; Wandell, 1989). Black locust is used throughout the world as a versatile landscape tree. It has proven to be highly effective in conditions that call for a species that is tolerant of air pollution and nutrient poor soils. Locust also has beautiful flowers, foliage, and stem structure that can grace parks and home gardens. The Europeans of the $18^{\text {th }}$ century planted this tree for ornamental purposes and the tree became very popular in European gardens (Peattie, 1950).

In several central European countries where black locust is an exotic, it is used extensively in plantation forestry for a variety of economic, ecological, and aesthetic purposes. Keresztesi (1988) reported that in 1986 there were about 69,000 acres $(28,000$ ha) of black locust forest in Czechoslovakia and some 670,000 acres $(271,000$ ha) in Hungary, which represents about $18 \%$ of this country's total forested area. It is also grown in China on 2.5 million acres ( 1 million ha), and South Korea on 3.0 million acres (1.22 million ha) (Keresztesi, 1988). Its widespread popularity has made black locust the $3^{\text {rd }}$ most planted hardwood tree in the world, only eucalypts and hybrid poplars are more widely used (Kerestesi, 1988). One of the reasons for its great success as an exotic in these countries is that some of the most damaging insect pests found in its native range, such as the locust borer, the

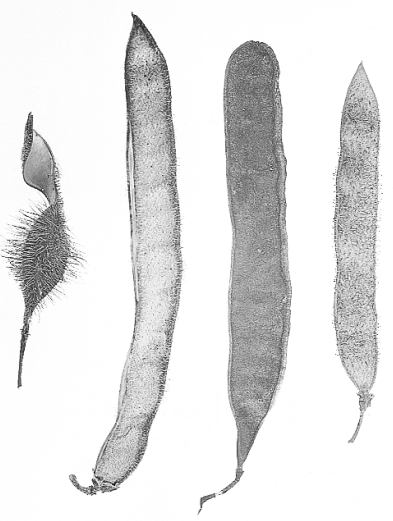

Fig. 1. Seed pods of (a) bristly locust (b), clammy locust, (c) black locust, and (d) new mexican locust $(2.54 \mathrm{~cm}$ $=1$ inch). 
locust leaf miner, and the locust twig borer, (Ecdytolopha insiticiana Zeller) do not occur and have thus far not been introduced into Europe or Asia (Hanover, 1992).

\section{Historical aspects}

Black locust was used by American Indians and subsequently by early American settlers. The spread of the species is believed to have started with the Native Americans before settlement of North America by Europeans (Sargent, 1892). William Strachey (Major, 1849), first secretary of the Virginian colony, upon visiting James River, Virginia in 1610, found "by the dwellings of the Indians are... a kynd [sic] of low tree, which bears a cod (pod) like to the peas, but nothing so big: we take yt [sic] to be locust." He further states that the "Indians made their bows of some plant, eyther [sic] of the locust-tree or of weech [sic]." Catesby (1763) states in his assessment of locust that both Virginians and American Indians were using locust for bows. Whether the native Americans spread this tree from its native range throughout the eastern United States will probably never be known for certain (Isely and Peabody, 1984) but there seems to be sufficient evidence that they were aware of the tree and many of its beneficial properties. Houses in the original settlements of Virginia, were said to have been built upon locust posts "pitched into the ground to support the four corners" (Catesby, 1763).

Sometime around the settlement of Jamestown, Virginia (1607) Jean Robin, herbalist to Henry IV of France, or his son Vespasien, introduced the first locust trees to Europe (Peattie, 1950). Black locust was first grown in England in 1630 (Mitchell, 1974), by 1710 it was being grown in Hungary (Vadas, 1911), and by 1720 in Slovakia (Bencat, 1982). Around 1817 William Cobbett, an Englishman, started grow-

Table 1. Cultivars of black locust from Jacobson (1996) except where otherwise noted $(1 \mathrm{ft}=0.3 \mathrm{~m})$.

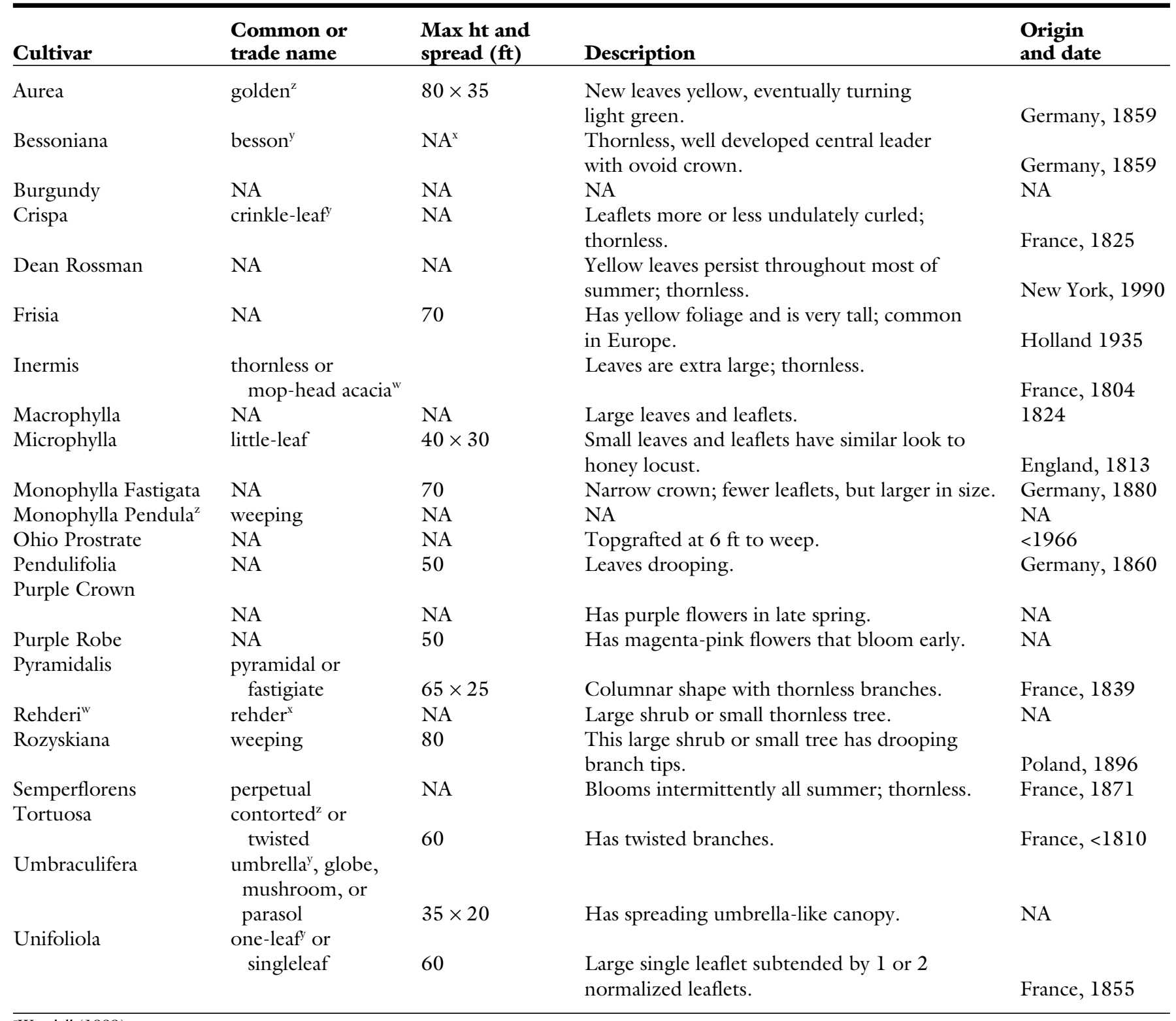

\footnotetext{
${ }^{\mathrm{z} W a n d e l l}(1989)$

y Vines (1960).

${ }^{\mathrm{x}} \mathrm{NA}=$ not available.

whillier (1973).
} 
ing black locust on his farm in New York. When he returned to England a few years later he imported millions of seeds and began selling locust trees in very large quantities (Peattie, 1950). From these beginnings black locust became very popular in Europe.

\section{Species, varieties, and cultivars}

The genus Robinia is part of the tribe Robinieae, a member of the legume subfamily Papilionoideae. Its most closely related genera are Coursetia DC, Genistidium I.M. Johnston, Olenya Gray, Peteria A. Gray, and Sphinctospermum Rose. These six genera make up the Robinia group and they have their origins in the southern United States and northern Mexico, except for Coursetia, which extends from the southwestern United States to central South America (Lavin, 1992). Workers during the early part of the twentieth century suggested as many as 20 species of Robinia (Ashe, 1922, 1923a, 1923b; Rydberg, 1924; Small, 1933). Recent taxonomic analysis indicates there are four species worldwide: R. pseudoacacia; $R$. hispida; $R$. viscosa; and $R$. neomexicana (Isely and Peabody, 1984; Mabberley, 1997) (Fig. 1).

Black locust, which has been the most widely used Robinia species (Keresztesi, 1980, 1983, 1988), is native to the Appalachian mountain regions of the eastern U.S with its northern most range in Pennsylvania, extending south to northern Georgia and Alabama (Little, 1971). Other native regions are found in southern Missouri, eastern Oklahoma, and western Arkansas (Little, 1971). Its present naturalized range extends throughout the eastern temperate regions of North America (Hanover et al., 1991). It is presently cultivated expansively throughout the cool temperate areas of the world (Lavin, 1992).

The only recognized black locust variety is the shipmast locust $(R$. psendoacacia var rectissima Raber) characterized by Raber (1936). Before Raber's documentation in 1936, shipmast locust had been recognized as a distinct variety by growers since the early 1800s (Hopp, 1942). Shipmast has a straight central stem that makes it ideal for many uses where durability, strength, and straightness are desired.

Due to the predominance of asexual reproduction by root sprouting there is genetic and morphological uniformity within a population but often there are marked differences between populations (Lavin, 1992). The difference in populations is most likely due to many clones comprising the stand. No evidence exists as to whether black locust will self-pollinate. Selfing is probably rare (B. Bongarten, personal communication). When workers attempt to develop superior clones it is done either with open-pollinated seedlots (half-sibs) or with controlpollinated seedlots (full-sibs) (Bloese et al., 1992). This natural variation among populations gives the impression that many Robinia species and varieties exist. Many cultivars and lines of seed of black locust are recognized and are used for many purposes including horticultural and reclamation purposes (Liberty Hyde Bailey Hortorium, 1976; Bridgen, 1992; Bongarten, 1992; Hillier, 1973; Jacobsen, 1996; Keresztesi, 1988; Vines, 1960; Wandell, 1989).

Horticultural cultivars have been selected for a variety of characteristics including; thornlessness, form, leaf and flower color, leaf size and shape, and blooming pattern (Nelson, 1976). The earliest known cultivar was developed in France and named in 1804 (Jacobson, 1996). Many of the horticultural cultivars of black locust are listed in Table 1. In Hungary many more cultivars are available for a variety of uses (Keresztesi, 1988).

Bristly locust is native from southwest Virginia to northern Georgia in the southern Appalachians, adjacent piedmont, and coastal plain (Isley and Peabody, 1984). This species has been widely planted throughout the eastern United States. Five varieties are recognized $R$. hispida var. fertilis (Ashe) Clausen, kelsey locust ( $R$. hispida var. kelseyi (Cowell ex Hutchinson) Isely), $R$. hispidavar. hispida Mant., R. hispida var. nana (Elliott) A.P. de Candolle, and $R$. hispida var. rosea Pursh. There are two cultivars listed by Wandell (1989) 'Macrophylia' and 'Superba' and the cultivar $R$. hispida var. fertilis 'Arnot', which has been used in land restoration (Carpenter and Hensley, 1979).

Clammy locust is native to the mountains of western North Carolina. It has been cultivated in the eastern United States as a shrub or small tree (Isley and Peabody, 1984). In addi- tion to the species type $R$. viscosa Ventenat, var. hartwigii (Koehne) Ashe is recognized.

New mexican locust is native to the southwestern United States. It is found in Arizona, Colorado, New Mexico, Texas, and Utah, with small populations in northern Sonora, Mexico (Little, 1976). This species is generally a shrub or small tree, but it has been found in isolated clumps as a tree, reaching heights of $75 \mathrm{ft}(22.9 \mathrm{~m})$ with straight stems (Wagner et al., 1992). The shrubby form is considered by many as a weed due to its ability to rapidly colonize sites following disturbance and low commercial value. Plant development work has begun at Northern Arizona University for its use as a landscape plant (M.R. Wagner, unpublished). It has been recognized for its outstanding flowering (Fig. 2) and seedlings are beginning to be used as ornamentals in the southwestern U.S.

Other species and varieties that have been described in the literature were found not to be true species or varieties and are most likely cultivars or hybrids of the previously described taxa (Isley and Peabody, 1984). Several of these hybrids have been described in the literature (Isley and Peabody, 1984; Wandell, 1989) and they are of horticultural interest. Flowering loose globe locust ( $R$. hispida $\times$ macrophylla 'Flowering Loose Globe

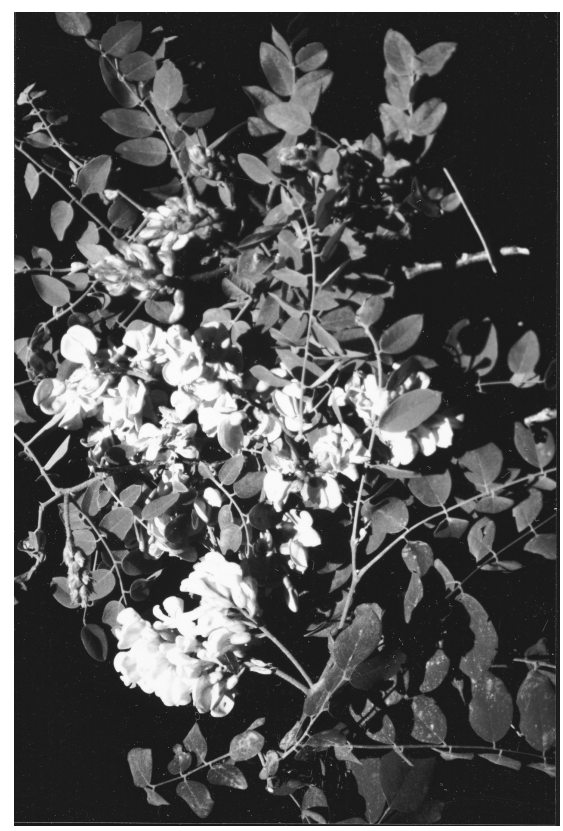

Fig. 2. Flowers of new mexican locust. 


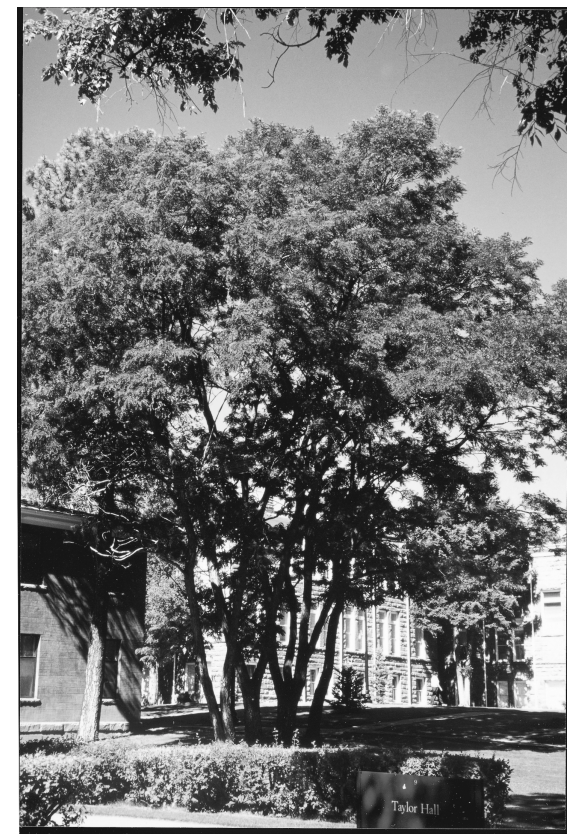

Fig. 3. Mature black locust.

Locust'), idaho locust ( $R$. xambigua 'Idahoensis'), and decaisneana ( $R$. xambigua 'Decaisneana') are three of the most commonly propagated hybrids.

Selection of superior plant material for use in the U.S. started in the 1930s and was spearheaded by the Soil Conservation Service (SCS), presently known as the Natural Resources Conservation Service (NRCS). Most cultivars have been selected based upon their growth rate and stem straightness with secondary considerations for locust borer resistance (Bongarten, 1992). Other institutions that have had active locust plant material selection programs in recent years are the University of Georgia, Michigan State University, the University of Kentucky, and the University of Maryland (B. Bongarten, personal communication).

\section{Growth habits}

Black locust forms a large-sized tree $75 \mathrm{ft}(22.9 \mathrm{~m})$ tall with a 40 to 50 $\mathrm{ft}$ (12.2 to $15.3 \mathrm{~m}$ ) crown spread (Fig. $3)$. Open, sparse branching creates a spreading top. It has light gray to brown, thick bark that is deeply furrowed with scaly ridges. Branches are upright, arching, and spiny; often with multiple stems. Foliage is deciduous and leafs-out in mid-spring depending upon region. Leaves are pinnate to 12 inches $(30.5 \mathrm{~cm})$ long with 11 to 21 elliptical to oval shaped leaflets (Fig. 4 ). Leaves turn yellow and are shed in early fall. Showy, insect-pollinated, fragrant pea-like white flower clusters (Fig. 5) in mid to late spring in most places followed by 4 inch $(10.2 \mathrm{~cm})$ long bean-like seedpods (DeGomez and Bailey, 1998).

Black locust has indeterminate growth, it is tolerant to a wide range of soil characteristics, and it develops an extensive root system (Bridgen, 1992). In natural systems it propagates via seed and root sprouts. As a typical pioneer species it uses gaps in the canopy and grows best in full sun. Black locust, depending on cultivar, is cold hardy to USDA zone 3,4 , or 5 (USDA, 1990).

Black locust has a tendency to produce multiple stems from root suckering. Multiple stemmed trees should be repeatedly pruned to one stem if specimen trees are desired. When unforked trunks are desired the bole should be pruned to a central leader, removing secondary leaders and lateral branches low on the bole (Keresztesi, 1988). When straight trunks are wanted select plant material with straight trunks and prune for unforked trunk. When a broad crown is desired pruning should encourage wide, strong lateral branching and secondary leaders should be removed. Use spreaders or other mechanical devices to widen the distance between the main stem and an upright lateral branch so as to discourage the lateral branch from competing with the central leader and thus encouraging a strong lateral branch.

Bunger and Thomson (1938) found mature black locust to have roots greater than $26 \mathrm{ft}(7.9 \mathrm{~m})$ deep in a Richfield silt loam soil. Cutler and Richardson (1981) found roots to be up to $4 \mathrm{lft}(12.4 \mathrm{~m})$ wide. Root width and depth will vary depending on soil and other conditions.

\section{Propagation}

Propagation can be accomplished with seed or vegetatively. Seeds are used when large numbers of plants are needed and more genetic variation can be tolerated, as with reforestation projects or for site restoration and stabilization. Vegetatively propagated plants are used when superior plants are desired for landscapes, seed orchards, or for the production of timber.

Seeding propagation. Black locust propagation by seed requires seed pretreatment with boiling water, acid, or mechanical scarification due to impermeable seed coat (Chapman, 1936; USDA Forest Service, 1974; Bujtas, 1992). Soaking the seeds in concentrated sulfuric acid from 10 to $120 \mathrm{~min}$ has been found to be effective (Meginnis, 1937), but each seed lot should be tested to determine proper length of time for soaking (Meginnis, 1937) due to variability of seed coat structure and permeability. Other workers have reported success with a variety of soaking times in sulfuric acid from 20 to $80 \mathrm{~min} ; 20 \mathrm{~min}$ (Arrillaga and Merkle, 1993), $45 \mathrm{~min} R$. pseudoacacia, $R$. neomexicana, and $R$. hispida (DeGomez, unpublished), 60 min (Hartmann et al., 1997), and 25 to $80 \mathrm{~min} R$. neomexicana (Lin et al., 1996). Following scarification with acid it is necessary to thoroughly rinse the seed with water or neutralize with baking soda. Mechanical scarification is fast and effective for large quantities of seed if the proper equipment is used (Chapman, 1936). Soaking seeds of $R$. hispida and R. viscosa in boiling water for $1 \mathrm{~min}$ will increase germination rates from none to $80 \%$ (Wilson, 1944). Soaking in near boiling water 25 to $80 \mathrm{~min}$ for R. neomexicana ( $\mathrm{Lin}$ et al., 1996) increases germination over soaking for $10 \mathrm{~min}$.

In Hungary, where 30 to 40 million seedlings are grown annually, seeds are sown in a furrow about 1.2 inches

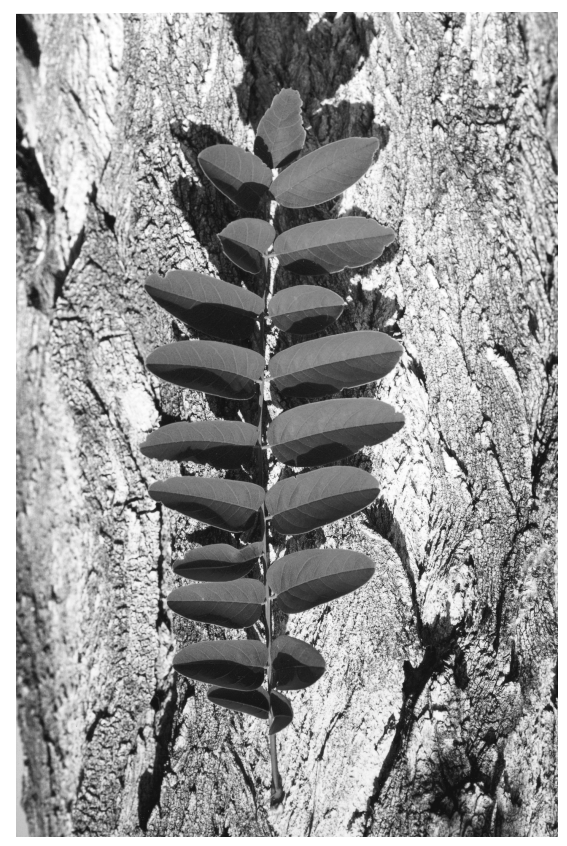

Fig. 4. Leaf and bark of black locust. 


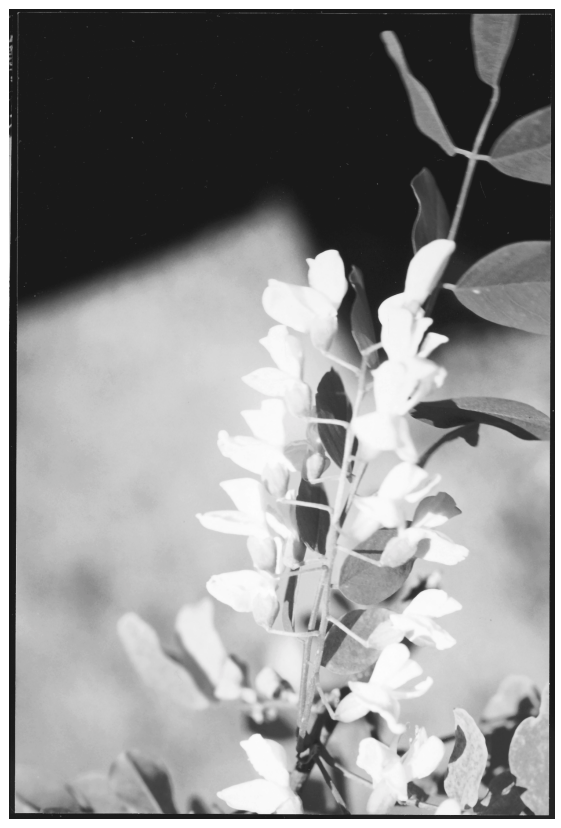

Fig. 5. Flowers of black locust.

$(3 \mathrm{~cm})$ deep at a rate of 40 to 50 seeds of $100 \%$ germination rate per running $3.3 \mathrm{ft}(1 \mathrm{~m})$ and covered with 0.8 to 1.2 inches ( 2 to $3 \mathrm{~cm}$ ) of soil. Rows are 14 tol 6 inches ( 35 to $40 \mathrm{~cm}$ ) apart for a density of 80 to 100 thousand/acre (200 to 250 thousand/ha) (Bujtas, 1992). In the Appalachian coal province of the U.S. seeds are direct seeded on mine-spoil sites via broadcast, or drilled at a rate of 1 to $3 \mathrm{lb} /$ acre (1.11 to $3.36 \mathrm{~kg} \cdot \mathrm{ha}^{-1}$ ) (Ashby et al., 1985).

Seeds can be stored for 10 or more years at 32 to $40^{\circ} \mathrm{F}\left(0\right.$ to $\left.5^{\circ} \mathrm{C}\right)$ or for 3 to 4 years when stored in a cool dry place (USDA Forest Service, 1974). Acid scarified seed can be stored without loss of viability for extended periods of time (Meginnis, 1937).

Vegetative propagation. Locust can be propagated vegetatively from root cuttings, softwood cuttings, or tissue culture. Root cuttings are typically used in Hungary when vegetative propagation is desired (Bujtas, 1992). They use either 3.1 to 3.9 inch ( 8 to 10 $\mathrm{cm})$ long root cuttings or 1.2 to 2.0 inch $(3$ to $5 \mathrm{~cm}$ ) root pieces taken from young plants grown specifically for this purpose. The longer root cuttings are planted vertically with the top cut surface about 0.8 inch $(1 \mathrm{~cm})$ below ground level. Root pieces should be sown in a furrow 3.9 inches $(10 \mathrm{~cm})$ wide and 1.6 inches $(4 \mathrm{~cm})$ deep at a rate of 8 to 9 root pieces / ft (25 to $30 /$ $\mathrm{m})$. Care should be taken not to bury the root pieces more than 1.6 inches $(4$ $\mathrm{cm})$ deep. Plant emergence can be expected to appear 20-25 d after planting in spring.

Softwood cuttings of black locust can be successfully propagated using the following methods (B. Bongarten, personal communication). Softwood cuttings from black locust trees should be taken in the spring when new growth is 8 inches $(20 \mathrm{~cm})$ long. These greensoftwood cuttings should be placed in water immediately. If cuttings are taken from basal or apical shoots they will have an upright growth whereas shoots from lateral growth will have plagitropic growth for the first 2 years. Before planting, the cuttings should be dipped in $12,000 \mathrm{ppm}\left(\mathrm{mg} \cdot \mathrm{L}^{-1}\right)$ indole-3-butyric-acid (IBA) in alcohol and in thiram fungicide (tetramethylthiuram-disulfide). The rooting media should be very course, $50 \%$ peat $/ 50 \%$ coarse perlite, to reduce the incidence of disease. The cuttings should be sprayed with Thiram once a week to further reduce the incidence of disease. They should be placed under mist for about $10 \mathrm{~s}$ every $15 \mathrm{~min}$, or if possible, put them in a fog of $100 \%$ relative humidity. Temperatures of about $65{ }^{\circ} \mathrm{F}\left(47^{\circ} \mathrm{C}\right)$ give the best results. Fertilize once a week with a balanced fertilizer including micronutrients.

Black locust can be successfully tissue cultured by many methods. Some of the earliest work used shoot nodal segments as the primary explant (Chalupa, 1983; Chalupa, 1992), and seedling-derived callus tissue (Brown and Sommer, 1982). Later workers have used dormant bud explants depending on the source plant (Davis and Keathley, 1987; Gruber and Hanover, 1992), cotyledon and in vitro-derived leaf explants (Arrillaga and Merkle, 1993), auxiliary bud explants obtained from clones propagated via stem or root cuttings from black locust (Barghchi, 1987) and axillary buds from new mexican locust plantlets (Lin and Wagner, 1996). Gruber and Hanover (1992) conducted an economic analysis of the feasibility of mass-producing black locust plants via in vitro techniques and they concluded that the cost was six to seven times that of unimproved seedlings.

Cultivars of trees used for ornamental purposes are typically grafted or budded onto rootstocks grown from seed because it is easier than other types of vegetative propagation for locust. Budding and grafting is often the only possible method of propagation for many plants (Dirr and Heuser, 1987). Most cultivars of bristly locust or black locust can be grafted using whip or side-veneer techniques onto black locust seedling rootstocks in the winter, and summer grafts can be successful with some cultivars (Dirr and Heuser, 1987).

\section{Spacing}

It was proposed in 1791 by British foresters to space locust trees in plantations at $16.5 \times 16.5 \mathrm{ft}(5 \mathrm{~m})$ or 160 trees/acre $(395 / \mathrm{ha})$ to produce trees of about 1.5 tons ( $1400 \mathrm{~kg}$ ) each (Gentleman's Magazine, 1791). Those recommendations of 200 years ago are very close to today's recommendation of $17.7 \mathrm{ft}(5.4 \mathrm{~m})$ for the final spacing in plantations for timber production in Hungary (Keresztesi, 1988) or in The Netherlands final spacing of high density plantations is $12.5 \mathrm{ft}(3.8 \mathrm{~m})$ (Robinia Foundation, 1992). The big difference between techniques of the $18^{\text {th }}$ century and today is the desire and techniques to use the growing spacing more efficiently throughout the life of the planting. Halupa et al. (Keresztesi, 1988) recommend planting trees in high density forest plantations $6.9 \mathrm{ft}$ $(2.1 \mathrm{~m})$ apart and progressively implementing two cleanings and three thinnings in the stand during the first 20 years, reaching a final stand density of 139 /acre (342/ha). In The Netherlands recommendations are for even closer spacing at planting of $4.6 \mathrm{ft}$ ( 1.4 $\mathrm{m}$ ) with three thinnings and a final cut at a maximum of 40 years of age (Robinia Foundation, 1992).

The initial close spacing that Halupa et al. (Keresztesi, 1988) proposed is for several reasons. First and foremost is for the production of straight stems for high value timber production and secondarily for the production of saleable wood products before the final harvest. The two cleanings decrease stem number from 1010 to $360 /$ acre $(2500$ to $900 /$ ha $)$. The small diameter wood harvested in these cuttings is used for fuel wood or chips. Thinning operations reduce the stand from $360 /$ acre $(900 /$ ha $)$ to the final density of $160 /$ acre (400/ha). Additional uses of these trees are for poles and posts.

Stem densities are much higher when the primary goal is land reclamation (increasing organic matter levels, 
reducing erosion, improving soil fertility) with the intent to harvest biomass and possibly timber at a much later date. Stem densities are higher because of reduced survival when planted on reclamation sites. In a survey of 72 reclamation sites in Kentucky used for biomass production the average range in stem density was $11,686 /$ acre $(28,714 /$ ha $)$ for 2 -year-old stands to $814 /$ acre $(2000 /$ ha $)$ for 13-year-old stands (Carpenter and Eigel, 1979). For reclamation of mine-spoil sites in the Interior Coal Province (Indiana to Kansas) 1-year-old seedlings are planted on $7 \times 7 \mathrm{ft}(2.1 \mathrm{~m})$ spacing. As the slope increases the planting distance shortens to a maximum density of $4 \times 4 \mathrm{ft}(1.2 \mathrm{~m})$ (Ashby et al., 1985). Limstrom (1960) found that a mixed planting of $50 \%$ locust with mixed hardwoods on strip-mined land at $7 \times 7 \mathrm{ft}$ spacing were highly successful.

Coppice systems are very common in locust plantations. In the case of these systems propagation occurs from cut stumps and root suckers. Stem densities are typically higher and total wood production lower due to the production of smaller diameter stems at final harvest when regeneration is from coppicing. Stem density for young stands ( 6 to 10 years) range from 1020 to $1425 /$ acre (2500 to $3500 / \mathrm{ha}$ ) and in the oldest stands ( 20 to 40 years) 225 to $815 /$ acre (550 to $2000 /$ ha) (Keresztesi, 1988). Similar cleanings and thinning operations are carried out in these stands as with high density forest plantations.

Spacing of ornamental trees is highly dependent upon the cultivar used and the planting site. Mature size and final effect desired should always be considered when deciding where to plant a landscape tree. Minimum cutout that black locust can be planted into a sidewalk is $5 \times 5 \mathrm{ft}(1.5 \mathrm{~m})$ (DeGomez and Bailey, 1998).

\section{Irrigation}

Black locust is considered drought resistant (Bunger and Thomson, 1938; Hanover, 1992). Raper et al. (1992) studied water use efficiency (WUE) for sweetgum (Liquidambarstyraciflua L.), american sycamore (Platanus occidentalis L.), and black locust. Water use efficiency is the measure of the water transpired compared to the biomass produced. Locust had a much lower WUE than did sweetgum or sycamore, 0.09 compared to 0.43 and 0.37 [biomass growth per unit land area $\left(\mathrm{g} \cdot \mathrm{m}^{-2}\right) /$ water transpired per unit land area $\left.\left(\mathrm{kg} \cdot \mathrm{m}^{-2}\right)\right]$, respectively. Ranney et al. (1990) found no significant difference in WUE among paper birch (Betula papyrifera Marsh), chinese elm (Ulmus parvifolia Jacq.), boxelder (Acer negundo L.), and black locust. They also found that locust used $24.5 \mathrm{lb}(11.1 \mathrm{~kg})$ of water to produce $0.035 \mathrm{oz}(\mathrm{lg})$ of biomass compared to $5.1 \mathrm{lb}(2.3 \mathrm{~kg})$ and $6.0 \mathrm{lb}(2.7 \mathrm{~kg})$ for sweetgum and sycamore. Ranney et al. (1990) studied water use in five species. They found that locust had a significant drop in osmotic potential at full hydration when grown under water stressed conditions. Furthermore, they found that locust under water stressed conditions lost leaf elasticity which generally limits leaf turgor. Significant loss of osmotic potential and leaf turgor led to leaf abscission. High amounts of leaf abscission when water stressed was responsible for low leaf root ratios for locust.

Weather conditions in Hungary make it possible to grow black locust from seed or transplants in the field without irrigation (Keresztesi, 1988; Bujtas, 1992). Typical April, May and June weather conditions in Hungary are relative humidity in afternoon of $50 \%$ and average monthly precipitation for April, May, and June is 2.0 inches (5.1 $\mathrm{cm})$. Root cuttings need to be irrigated if the soil surface dries out. After the shoots from root cuttings are 3.9 to 5.9 inches ( 10 to $15 \mathrm{~cm}$ ) high irrigation can be reduced and the top 1.6 to 2.0 inches (4 to $5 \mathrm{~cm}$ ) of soil can dry out before irrigating again (Bujtas, 1992).

\section{Plant and soil nutrition}

Ease of cultivation and fast growth are just a few reasons why black locust has been so successful as a site restoration plant. The main reason why black locust performs so well on a variety of sites is its ability to fix nitrogen. Nitrogen fixation not only benefits locust but also other species in the stand (Ashby and Baker, 1968). Nitrogen fixing forest species are rare in most forest types and locust contributes tremendous amounts of nitrogen to the forest ecosystem (Boring and Swank, 1984).

Since locust is a nitrogen fixing plant it has lower soil nitrogen requirements than non-nitrogen fixing plants, but studies have shown that phosphorous applications can be of benefit. Annual nitrogen fixation rates for black locust can vary from $26 \mathrm{lb} /$ acre $(30$ $\mathrm{kg} \cdot \mathrm{ha}^{-1}$ ) for a 4 year old chestnut-oak
(Castanea Miller and QuercusL.) hardwood forest (Boring and Swank, 1984) to 96 to $244 \mathrm{lb} / \mathrm{acre}\left(108\right.$ to $274 \mathrm{~kg} \cdot \mathrm{ha}^{-1}$ ) for a 5-18 year old seeded surface mine. These values compare favorably with forage and grain legumes (Bridgen, 1992). Phosphorous fertilizer at $99 \mathrm{lb} /$ acre $\left(112 \mathrm{~kg} \cdot \mathrm{ha}^{-1}\right)$ has been shown to enhance growth on acidic surface mine soils when used alone or with $50 \mathrm{lb} /$ acre $\left(56 \mathrm{~kg} \cdot \mathrm{ha}^{-1}\right)$ of nitrogen applications (Plass, 1972). McComb and Kapel (1942) found that nitrogen and potassium fertilizers 139 and $110 \mathrm{lb} / \mathrm{acre}$, respectively ( 157 and $123 \mathrm{~kg} \cdot \mathrm{ha}^{-1}$ ), had no effect unless phosphorous at $270 \mathrm{lb} /$ acre $\left(303 \mathrm{~kg} \cdot \mathrm{ha}^{-1}\right)$ was added. Other studies have shown that applications of nitrogen can be detrimental to locust, which is similar to the effect of nitrogen on other nitrogen-fixing plants. Bridgen (1992) found that nitrogen applications on soils low in nitrogen caused a decrease in growth of black locust.

Black locust dominated forest stands have higher levels of ammonium nitrogen than do stands that are dominated by pine or mixed hardwoods. As a result higher levels of nitrification were found in black locust stands (Montagnini et al., 1989). In a subsequent study Montagnini et al. (1991) found higher soil solution levels of nitrate nitrogen. The primary source of nitrogen is from nitrogen fixing bacteria, subsequently nitrogen will make its way into soil solution from root exudation and from the foliage. When compared to autumn olive (Elaeagnus umbellata Thumb.), honey locust (Gleditisia triacanthosL.), and american sycamore, black locust had significantly less net foliar nitrogen decline at senescence (Vogel and Dawson, 1993), perhaps explaining in part the high soil solution levels of nitrate nitrogen.

Black locust can also be used as a catalyst for other trees on mine-spoils (Ashby and Baker, 1968; Auten 1945; Boyce and Merz, 1959; Jencks, 1982; Limstrom, 1960). When six species of hardwoods \{black walnut (Juglans nigra L.), yellow-poplar (Liriodendron tulipifera L.), silver maple (Acer saccharinum L.), sweetgum, osage orange [Maclura pomifera (Raf.) Schneid.]\}, and ash (Fraxinus L.) were grown in the understory of black locust or shortleaf pine (Pinusechinata Miller) in southern Illinois, only sweetgum grew better in the pine understory (Ashby and Baker 1968). Characteristics of black locust as a catalyst tree are reducing soil 
erosion by rapid colonization of the site, nitrogen fixation by Rhizobium Frank bacteria, high nitrogen levels in leaf litter, and high leaf litter volumes in the early stages of succession.

To ensure that nodulation and nitrogen fixation occurs, plants derived from seed, stem cuttings, or tissue culture need to be inoculated with Rhizobium bacteria before planting. Following seed scarification or when preparing cuttings for rooting it is necessary to inoculate the seed or cuttings with Rhizobium bacteria specifically cultured for Robinia. It is recommended to test various strains of Rhizobium because of genetic variation in bacteria (Batzli et al., 1992).

Robinia appears to be tolerant of a wide range of soil $\mathrm{pH}$ but will grow best when the $\mathrm{pH}$ is near neutral. In southwest Indiana black locust and R. hispida var. fertilis 'Arnot' [R. fertilis (Ashe.)] had good survival (40 and $45 \%$ respectively) on low pH soil (2.85) and when the $\mathrm{pH}$ was raised to 6.0 or higher survival was $70 \%$ for both black locust and bristly locust (Carpenter and Hensley 1979). In Kentucky, survival rates were $90 \%$ to $97 \%$ on low pH $(2.9$ to 4.0 ) strip-mine soils, in addition these soils were low in extractable phosphate (Plass, 1972). Applications of lime on low $\mathrm{pH}$ soils have been shown to significantly increase seedling growth (Carpenter and Hensley, 1979; McComb and Kapel, 1942; Tingxiu and Guofan, 1988).

\section{Insects}

Of the hundreds of insects associated with locust in the United States, only a few have been found to significantly impact growth and survival (Alford, 1991; Athey and Connor, 1989; Drooz, 1985; Furniss and Carolin, 1977; Hall, 1937; Hoffard, 1992; Hoffard and Anderson, 1982; Hopkins, 1907; Johnson and Lyon, 1991; Wagner et al., 1992; T. DeGomez and M.R. Wagner, unpublished). Total biomass production was unaffected by low levels of herbivory and did not stimulate biomass and nutrient accretion (Seasteat et al., 1983). However, herbivory can be very heavy on black locust. Pests can remove $75 \%$ or more of the photosynthetic area on single trees (Athey and Connor, 1989).

Only 76 species of insects had been reported on locust in the United States as of 1991 (Alford, 1991; Drooz, 1985; Furniss and Carolin, 1977; Hoffard,
1992; Johnson and Lyon, 1991; Wagner et al., 1992). T. DeGomez and M.R. Wagner (unpublished) found 333 species of arthropods associated with locust in northern Arizona. In South Slovakia, 33 species from the insect order Lepidoptera were collected in a 3-year survey of locust insects (Kulfan, 1991). This is a high number of species considering only 23 species of Lepidoptera are listed on locust in the United States. Of these hundreds of insects, three have caused the most damage and will be discussed here.

LOCUST BORER. The locust borer (Coleoptera: Cerambycidae), is the most devastating insect on black locust and it is presently confined to North America. Locust is a classic example of a plant from the Americas that is maligned by a native insect but, has proven to be extremely valuable when grown elsewhere without pressure from its most destructive pest.

Damage to black locust by the locust borer is severe. The locust borer larvae attack the trunks and twigs of the tree. Hopkins (1907) reported that borers prefer trees with thinner bark vs. the coarse bark found on mature trees. The newly hatched larvae bore through the bark and into the cambial layer where they overwinter. In the spring, larvae continue to feed creating a $\mathrm{l}$ inch $(25 \mathrm{~mm})$ diameter by 4.7 inch $(12 \mathrm{~cm})$ long tunnel (Johnson and Lyon, 1991). Damage caused by a single borer would be of little consequence, but repeated attacks in subsequent years causes the trees to become weak and to break in wind storms. Death is rare from borer attack, but severely attacked trees are reduced to being good only for fuelwood. The value of shade and specimen trees is destroyed when infested with borers.

Resistance to locust borer has been of great interest to entomologists and plant breeders. Several workers thought that specific clones were more resistant because of superior vigor (Hall, 1937). However, there is no evidence that any black locust clone has shown resistance. There has been evidence that young, vigorously growing trees minimize borer damage by closure of wounds (Berry, 1945; Harman and Dixon, 1984).

LOCUST Leaf MINER. According to Hoffard (1992) the locust leaf miner, (Coleoptera: Chrysomelidae) is probably the best known insect pest on black locust. Damage can be so severe that trees will appear to have been burned in a forest fire. Damage to ornamental trees distracts from the beauty of the tree. Infestations can cover tens of thousands of acres. Hoffard and Anderson (1982) describe the adult beetle as being 0.25 inches $(6 \mathrm{~mm})$ long and that its feeding skeletonizes the leaves. He further indicates that the larvae mine the leaves turning them brown. Death can occur to the tree if two flushes of growth are produced in one growing season and each is consumed by the beetle (Johnson and Lyon, 1991). Athey and Connor (1989) reported herbivory from this insect ranged from $5.9 \%$ to $45.9 \%$ in their plots and that individual trees were as much as $\mathbf{5 0} \%$ defoliated. They observed that the adults caused much more damage than the larvae.

Locust tWig BORER. The locust twig borer, (Lepidoptera: Torticidae) can cause serious damage in young trees (Hoffard and Anderson, 1982). Hoffard and Anderson (1982) describe the insect as follows: Full grown larvae are 0.5 to 0.75 inches $(1.3$ to $1.9 \mathrm{~cm}$ ) long. These caterpillars bore into the twigs and feed on the vascular tissue. They cause the stem to swell and often the infected area will crack open and the twig will bend at the point of infection. With two generations peryear, repeated attack can kill small seedlings. Adult moths have a wingspan of 0.75 to 1.0 inch (1.9 to $2.5 \mathrm{~cm})$.

\section{Pathogens}

Heart rot fungus [Phellinus robineae (Murr.) A. Ames] is the most important black locust disease. This disease enters the tree via wounds, such as those made by locust borer, fire or other mechanical wound, and causes the heart wood to become brown, lightweight, and crumbly (Hoffard and Anderson, 1982). Damage to the wood destroys its practical use. Controls include reducing wounding and planting at close spacing to encourage natural pruning, thus limiting large branches and subsequent large branch stubs.

\section{Use}

Locust's greatest use in the United States is in land reclamation; especially on mine spoils, and eroded farm and pasturelands. The wood has been highly valued since its first discovery by European settlers in America and by the native Americans before them (Catesby, 1763; Major, 1849). In 1791 it was proposed that the British Crown plant 10,000 acres $(4,000 \mathrm{ha})$ of land 
to locust for use in building ships for the British Navy. As stated in the article, "locust wood is found, by American shipwrights, to be singularly useful in making the upperworks of large ships and such parts of vessels as are likely to decay soon (Gentleman's Magazine, 1791). This account is likely the first recorded where locust was proposed for large-scale plantation forestry. The earliest record of locust wood being exported is in an article by Loudon (1844) who detailed that in 1819 locust treenails (wooden pegs used in construction) were sold in Philadelphia for $\$ 10$ per thousand and that 50 to 100 thousand were exported to England each year. The wood has exceptionally high decay resistance (Forest Products Laboratory, 1987) and is highly valued for poles and posts. The wood can also be used when a strong or extremely hard wood is needed. In the Netherlands uses for the wood are flooring and outdoor furniture (Robinia Foundation, 1992). In Hungary it is used for many purposes; trees are used for timber, fiberboard, poles, and firewood; the leaves are used for forage; and the flowers are highly valued for their source of nectar and pollen for honeybees (Apis mellifera L.) (Keresztesi, 1980). The honey is prized for its light color, mild flavor, and because crystallization takes place slowly (Keresztesi, 1988). Furthermore, the value of honey production is generally enough to pay the cost of establishment of plantations on 30 year rotations (Keresztesi, 1988).

Reclamation. Surface mine reclamation has been the most common use of locust in the United States in recent decades. Black locust has been planted and seeded more than any other species on surface-mined land in the eastern U.S. (Ashby et al., 1985). A 1990 study of the West Virginia State Nursery revealed that $95 \%$ of all black locust seedlings were being used in mine land reclamation projects (Bridgen, 1992). Black locust's ability to aggressively occupy a site through root growth and sprouts may make it desirable for other related uses. Black locust not only outgrows most species, but also has proven to be a good nurse tree for other species used in mixed plantings (Boyce and Merz, 1959; Limstrom, 1960).

BLACK LOCUST WOOD PROPERTIES. The mechanical properties of black locust wood are comparable to shag- bark hickory (Carya ovata Mill.). Shagbark hickory has a slightly higher specific gravity and static bending than black locust. Black locust has greater strength when compressed parallel and perpendicular to the grain, and has greater shear strength parallel to the grain. Black locust is much harder than sugar maple (Acer saccharum Marsh.), american ash (Fraxinusamericana L.), white oak (Quercus alba L.), or black walnut. The wood has a greenish tinge when freshly cut but darkens to a brown when exposed to air (Forest Products Laboratory, 1987).

Resistance of black locust wood to decay is legendary, it has been said in folklore that "when using it for fences it will last 2 years longer than stone". The Forest Products Laboratory (1987) only lists four domestic woods as having exceptionally high decay resistance and black locust is among those. Koloc (Keresztesi, 1988) reported that the heart wood has retained its integrity after being exposed to open weather for 80 years, 500 years under permanently moist conditions, and 1500 years in dry conditions. Black locust generally contains only 3 to 4 years of sapwood (Hills, 1987). With so little sapwood, the wood contains a high proportion of heartwood. The beauty of the wood has been compared favorably with black walnut for appearance and grain pattern, and its workability and durability has been compared to teak (Tectona grandis L. f.) (Hanover, 1992). Shukla et al. (1986) compared it's workability to ash (Fraxinus L.). These characteristics make the wood highly desirable for many uses. The Wood Handbook (Forest Products Laboratory, 1987) states that the best uses are for mine timbers, fenceposts, poles, railroad crossties, stakes and fuel. In Hungary it is used in similar ways but also for fine furniture (Redei, 1992).

BLACK LOCUST FOR PULP. Since black locust is very fast growing and has a high specific gravity it has drawn interest from the pulp and paper industry. Where black locust has been planted or has naturalized it has been used in mixed hardwood pulping processes (Smith, 1992). Kobor and Rob (1984) reported that black locust produces an acceptable kraft pulp. Low-grade black locust wood could be used to a greater degree as pulp if future supplies are predictable.

Fuelwood and BIomass. The ideal firewood/biomass producing species are fast growing and have wood with a high specific gravity. Unfortunately most fast growing species such as cottonwood (Populus L.), willow (Salix L.), or loblolly pine (Pinus taeda L.) have low specific gravity, $0.36,0.39$ and 0.51 respectively (Forest Products Laboratory, 1987). Black locust is not typical of fast growing trees. Black locust's fast growth rates, 0.78 to 2.4 inches $/ \mathrm{d}(2$ to $6 \mathrm{~cm} / \mathrm{d})$ (Hanover 1992), and high specific gravity, 0.69 (Forest Products Laboratory, 1987), places it among the leaders of domestic woody plants in the combination of these characteristics. The National Academy of Sciences (1983) rated black locust the number one firewood species in the United States. Since firewood is purchased by a volumetric measurement, black locust's high specific gravity makes it one of the best values when purchasing firewood on a volumetric basis.

\section{Overview}

Locust is a species with many great attributes. Ecologically it has the ability to quickly colonize a site that is in danger of eroding and as an early pioneer species it leaves the site in a state that can then be occupied by other late succession species. In that role it contributes levels of nitrogen that rival agronomic legumes. In the utilitarian realm the species grows very fast producing biomass that can be used for many purposes. In Hungary the honey produced in black locust plantations pays for the cost of establishment. Locust honey accounts for $50 \%$ to $60 \%$ of that country's total production annually (Keresztesi, 1988).

Insect pests prevent black locust from becoming an important timber and ornamental tree in its native range of the central Appalachian states. Unfortunately these insect pests are not going away and no economical method of control has as yet been devised.

\section{Literature cited}

Alford, D.V. 1991. A colour atlas of pests of ornamental trees, shrubs, and flowers. Wolfe Publishing London.

ArborVillage Nursery. 1997. Plants for gardeners. ArborVillage Nursery, Holt, Mo.

Arrillaga, I. and S.A. Merkle. 1993. Regenerating plants from in vitro culture of black locust cotyledon and leaf explants. HortScience 28:942945 
Ashe, W.W. 1922. The eastern shrubby species of Robinia. J. Elisha Mitchell Sci. Soc. 37:175-177.

Ashe, W.W. 1923a. Robinia. Notes on shrubs of the southeastern states. J. Elisha Mitchell Sci. Soc. 39:111-112.

Ashe, W.W. 1923b. Robinia. Notes on trees and shrubs of the southeastern United States. Rhodora $25: 180-183$

Ashby, W.C. and M.B. Baker, Jr. 1968. Soil nutrients and tree growth under black locust and shortleaf pine overstories in strip-mine plantings. J. For. 66:67-71.

Ashby, W.C., W.G. Vogel, and N.F. Rogers. 1985. Black locust in the reclamation equation. USDA For. Serv. N.E. For. Expt. Sta. Gen. Tech. Rpt. NE-105. p. 12.

Athey, L.A. and E.F. Connor. 1989. The relationship between foliar nitrogen content and feeding by Odontota dorsalis Thun. on Robinia pseudoacacia L. Oecologia 79:390-394.

Auten, J. T. 1945. Relative influence of sassafras, black locust, and pines upon old-field soils. J. For. $43: 441-446$.

Liberty Hyde Bailey Hortorium. 1976. Hortus third: A concise dictionary of plants cultivated in the United States and Canada. MacMillian., New York.

Barghchi, M. 1987. Mass clonal propagation in vitro of Robinia psendoacacia L. (black locust) cultivar Jaszkiseri. Plant Sci. 53:183-189.

Batzli, J.M., W.R. Graves, and P. Vanberkum. 1992. Diversity among Rhizobia effective with Robinia psundoacacia L. Appl. Environ. Microbiol. (July):2137-2143.

Bencat, F. 1982. Atlas of the distribution of exotic woody plants in Slovakia and zoning of their cultivation. Veda, Vydavatelstvo Slovenskej Akademie Vied, Bratislava.

Berry, F.H. 1945. Effect of site and the locust borer on plantations of black locust and black walnut. J. For. 43:751-754.

Bloese, P., J.W. Hanover, and B.C. Bongarten. 1992. Inheritance of juvenile traits and predicted gains from selection in black locust progeny tests in Mich. and Ga., p. 97-107. In: J. Hanover, K. Miller, and S. Plesko (eds.). Proc. Intl. Conf. on Black Locust: Biology, Culture, and Utilization, East Lansing, Mich., 17-21 June 1991.

Bongarten, B. 1992. Genetic variation in black locust within its native range, p. 78-97. In: J. Hanover, K. Miller, and S. Plesko (eds.). Proc. Intl. Conf. on Black Locust: Biology, Culture, and Utilization, East Lansing, Mich., 17-21 June 1991.

Boring, L.R. and W.T. Swank. 1984. Symbiotic nitrogen fixationin regenerating blacklocust (Robinia pseudoacacia) stands. For. Sci. 30:528-537.

Boyce, S.G. and R.W. Merz. 1959. Tree species recommended for strip mine plantations in western Ky. USDA For. Serv. Central States For. Expt. Sta. Tech. Paper 160. p. 12.

Bridgen, M.R. 1992. Plantation of black locust, p. 21-32. In: J. Hanover, K. Miller, and S. Plesko (eds.). Proc. Intl. Conf. on Black Locust: Biology, Culture, and Utilization, East Lansing, Mich., 17-21 June 1991.

Brown, C.L. and H.E. Sommer. 1982 Vegetative propagation of dicotyledonous trees, p. 109149. In: J.M. Bonga and D.J. Durzan (eds.). Tissue culture in forestry. Martius Nijhoff, Junk Publishers, The Hague, The Netherlands.

Bujtas, Z. 1992. Seed and root propagation of black locust, p. 49-53. In: J. Hanover, K. Miller, and S. Plesko (eds.). Proc. Intl. Conf. on Black Locust: Biology, Culture, and Utilization, East Lansing, Mich., 17-21 June 1991.

Bunger, M.T. and H.J. Thomson. 1938. Root development as a factor in the success of failure of windbreak trees in the southern high plains. J. For. 36:790-803.

Carlton Plants. 1997. Catalog. Carlton Plants, Dayton, Ore.

Carpenter, S.B. and R.A. Eigel. 1979. Reclaiming southern Appalachian surface mines with black locust fuel plantations, p. 221-227. In: R.W. DeVore (ed.). Symp. on Surface Mining Hydrology, Sedimentology and Reclamation, Uni. of Ky., Lexington, 4-7 Dec. 1979.

Carpenter, S.B. and D.L. Hensley. 1979. Utilizing $\mathrm{N}_{2}$-fixing woody plant species for distressed soils and the effect of lime on survival. Botanical Gaz. 140(Supplement):S76-S81.

Catesby, M. 1763. Hortus Britanno-Americanus: Curious collection of trees and shrubs. W. Richardson and S. Clark, London.

Chalupa, V. 1983. In vitro propagation of willows (Salix spp.), european mountain-ash (Sorbus arcuparia L.) and blacklocust (Robiniapseudoacacia L.). Biologis Plantarum 25:305-307.

Chalupa, V. 1992. Tissue culture propagation of black locust, p. 115-125. In: J. Hanover, K. Miller, and S. Plesko (eds.). Proc. Intl. Conf. on Black Locust: Biology, Culture, and Utilization, East Lansing, Mich., 17-21 June 1991.

Chapman, A.G. 1936. Scarifiaction of black locust seed to increase and hasten germination. J. For. 34:66-74.

Cutler, D.F. and I.B.K. Richardson. 1981. Tree roots and buildings. Construction Press, London.

Davis, J.M. and D.E. Keathley. 1987. Different responses to in vitro bud culture in mature Robinia pseudoacacia L. (black locust). Plant Cell Rpt. $6: 431-434$

DeGomez, T. and J. D. Bailey. 1998. Beyond the ponderosa: Successful landscape trees for the higher elevations in the Southwest, p. 68. Flagstaff Community Tree Board, Flagstaff, Ariz.

Dirr, M.A. and C. W. Heuser. 1987. The reference manual of woody plant propagation: From seed to tissue culture. Varsity Press, Athens, Ga.

Drooz, A.T. 1985. Insects of eastern forests. USDA For. Serv. Misc. Publ. 1426. U.S. Govt. Printing Office, Wash., D.C.
Forest Products Laboratory. 1987. Wood handbook: Wood as an engineering material. USDA Agr. Hdbk. No. 72. U.S. Govt. Printing Office, Wash., D.C.

Furniss, R.L. and V.M. Carolin. 1977. Western forest insects, USDA For. Serv. Misc. Publ. 1339. U.S. Govt. Printing Office, Wash., D.C.

Gentleman's Magazine. 1791. A plan for growing locust trees, \& etc. for the use of the royal navy. Volume LXI, Part II, p. 699-700.

Graham, A. 1987. Tropical American tertiary floras and paleoenvironments: Mexico, Costa Rica, and Panama. Amer. J. Bot. 74:1519-1531.

Gruber, K.F. and J.W. Hanover. 1992. An effective protocol for large scale micropropagation of black locust (Robinia psendoacacia), p. 126-135 In: J. Hanover, K. Miller, and S. Plesko (eds.). Proc. Intl. Conf. on Black Locust: Biology, Culture, and Utilization, East Lansing, Mich., 17-21 June 1991.

Hall, R.C. 1937. Growth and yield in shipmast locust on Long Island and its relative resistance to locust borer injury. J. For. 35:721-727.

Hanover, J.W., T. Mebrathu, and P. Bloese. 1991. Genetic improvement of black locust: A prime agroforestry species. For. Chronicle 67:227-231.

Hanover, J.W. 1992. Black locust: An historical and future perspective, p. 7-18. In: J. Hanover, K. Miller, and S. Plesko (eds.). Proc. Intl. Conf. on Black Locust: Biology, Culture, and Utilization, East Lansing, Mich., 17-21 June 1991.

Harman, D.M. and K.R. Dixon. 1984. External manifestation and closure of wounds caused by locust borers (Cloeoptera: Cerambycidae) on black locust subjected to certain wood decay fungi. J. Econ. Entomol. 77:1412-1420.

Hartmann, H.T., D.E. Kester, F.T. Davies, Jr., and R.L. Geneve. 1997. Plant propagation principles and practices. $6^{\text {th }}$ ed. Prentice Hall, Upper Saddle River, N.J.

Hillier, H.G. 1973. Hillers manual of trees \& shrubs. A.S. Barnes, New York.

Hillis, W.E. 1987. Heartwood and tree exudates. Springer-Verlag, New York.

Hoffard, W.H. and R.L. Anderson. 1982. A guide to common insects, diseases, and other problems of black locust. S.E. Area For. Rpt. SAFR19. USDA, For. Ser., Atlanta, Ga.

Hoffard, W.H. 1992. Insect pests of black locust, p. 44-52. In: J. Hanover, K. Miller, and S. Plesko (eds.). Proc. Intl. Conf. on Black Locust: Biology, Culture, and Utilization, East Lansing, Mich., 17-21 June 1991.

Hopkins, A.D. 1907. The locust borer and methods for its control. Circ. 83, USDA Bur. of Ento., Wash. D.C.

Hopp, H. 1942. Mystery among locusts. Amer. For. 48:27-30.

Isely, D. and F.J. Peabody. 1984. Robinia 
(Leguminosae: Papilionoidea). Castanea 49:187202.

Jacobson, A.L. 1996. North American landscape trees. Ten Speed Press, Berkeley, Calif.

Jencks, E.M., E.H. Tyron, and M. Contri. 1982. Accumulation of nitrogen in minesoils seeded to black locust. Soil Sci. Soc. Amer. J. 46:1290-1293.

Johnson, W.T. and H.H. Lyon. 1991. Insects that feed upon trees and shrubs. $2^{\text {nd }}$ ed. Cornell University Press, Ithica, N.Y.

Keresztesi, B. 1980. The black locust. Unasylva 32(127):23-33.

Keresztesi, B. 1983. Breeding and cultivation of black locust, Robinia pseudoacacia, in Hungary. For. Ecol Mgt. 6:217-244.

Keresztesi, B. 1988. The black locust. Akademai Kaido: Budapest, Hungary.

Kobor, L. and A. Rob. 1984. Possibilities of paper pulp manufacture from acacia (Robinia) wood. Papiripar 28:208-213.

Kulfan, M. 1991. The larvae of leaf-eating insects (Lepidoptera, Hymenoptera) on black locust (Robinia pseudoacacia) in South Slovakia. Biologia (Bratislava) 46(10):927-935.

Lavin, M. 1987. A cladistic analysis of the tribe Robinieae, p. 31-64. C.H. Stirton (ed.). In: Advances in legume systematics. part 3. Royal Botanica Gardens, Kew, England.

Lavin, M. 1992. Evolutionary relationships of the genus Robinia, p. 61-77. In: J. Hanover, K. Miller, and S. Plesko (eds.). Proc. Intl. Conf. on Black Locust: Biology, Culture, and Utilization, East Lansing, Mich., 17-21 June 1991.

Limstrom, G.A. 1960. Forestation of strip-mine land in the central states. USDA Agr. Hdbk. 166. U.S. Govt. Printing Offfice, Wash., D.C.

Lin, Y. and M.R. Wagner. 1996. Regeneration of plantlets from axillary buds of Robinia neomexicana. For., Farm, and Community Tree Res. Rpt. 1:107-111.

Lin, Y., M.R. Wagner, C.H. Seweyestewa, A. Honahni, M. DeGomez, and J.D. McMillin. 1996. Influence of cultural treatments on seed germination and seedling growth Robinia neomexicana. For., Farm, and Community Tree Res. Rpt. 1:112-116.

Little, Jr., E.L. 1971. Atlas of United States trees (native and naturalized). USDA For. Serv., Agr. Hdbk. 541. U.S. Govt. Printing Office, Wash. D.C.

Little, Jr., E.L. 1976. Atlas of United States trees. vol. 3 Minor western hardwoods. USDA For. Serv. Misc. Publ. 1314. U.S. Govt. Printing Office, Wash. D.C.

Loudon, J.C. 1844. Arboretun et Fruticetum Britannicum. vol. 2. J.C. Loudon, London, Eng. p. 619.

Mabberly, D.J. 1997. The plant book: A portable dictionary of the vascular plants. Cambridge Univ. Press, Cambridge, U.K.
Major, R.H.(ed.). 1849. The Historie of Travaile into Virginia Britannia (original manuscript by William Strachey, Gent.). Hakluyt Society, London, Eng. p. 129-130.

McComb, A.L. and F.J. Kapel. 1942. Effect of subsoil acidity and fertility on the growth of seedling black locust and green ash. Plant Physiol. 17:7-15.

Meginnis, H.G. 1937. Sulfuric acid treatment to increase germination of black locust seed. USDA Circ. 453, U.S. Govt. Printing Office, Wash. D.C.

Mitchell, A. F. 1974. A field guide to the trees of britain and northern Europe. Collins, London.

Montagnini, F., B. Haines, and W.T. Swank. 1991. Soil-solution chemistry in black locust, pine/mixed-hardwoods and oak/hickory forest stands in the southern Appalachians, U.S.A. For. Ecol. Mgt. 40:199-208.

Montagnini, F., B.L. Haines, W.T. Swank, and J.B. Waide. 1989. Nitrification in undisturbed mixed hardwoods and manipulated forests in the southern Appalachian mountains of North Carolina, U.S.A. Can. J. For. Res. 19: 1226-1234.

National Academy of Sciences. 1983. Firewood crops: Shrubs and tree species of energy production. vol. 2. Board on Sci. Technol. for Intl. Dev., Natl. Acad. Press, Wash. D.C.

Nelson, Jr., W.R. 1976. Esthetic considerations in the selection and use of trees in the urban environment, p. 13-24. In: F.S.Santamour, Jr., H.D. Gerhold, and S. Little. Better trees for metropolitan landscapes. U.S. Govt. Printing Office, Wash. D.C.

Nowak, D.J. and T.D. Sydnor. 1992. Popularity of tree species and cultivars in the United States. USDA For. Serv. Gen. Tech. Rpt. NE-166, Radnor, Pa.

Peattie, D.C. 1950. A natural history of trees of eastern and central North America. $2^{\text {nd }}$ ed. Houghton Mifflin, Boston.

Plass, W.T. 1972. Fertilization treatments increase black locust growth on extremely acid surface-mine spoils. Tree Planter's Notes 23(4):10-12.

Raber, O. 1936. Shipmast locust: A valuable underdescribed variety of Robinia pseudoacacia. USDA Circ. 379, USDA, U.S. Govt. Printing Office, Wash. D.C. p. 8.

Ranney, T.G., T.H. Whitlow, and N.L. Bassuk. 1990. Response of five temperate deciduous tree species to water stress. Tree Physiol. 6:439-448.

Raper, S.M., K. Steinbeck, I.S. Moss, and D. Whitehead. 1992. Water use efficiency and transpiration of Robinia, Liquidambar, and Platanus sprouts in the southeastern USA. For. Ecol. Mgt. 51:259-268.

Redei, K. 1992. Management of black locust stands in Hungary, p. 38-43. In: J. Hanover, K. Miller, and S. Plesko (eds.). Proc. Intl. Conf. on Black Locust: Biology, Culture, and Utilization, East Lansing, Mich., 17-21 June 1991.
Robinia Foundation. 1992. Feasibility study of Robinia pseudoacacia in The Netherlands. Robinia Foundation, Wageningen, The Netherlands.

Rydberg, P.A. 1924. Fabaceae: Galageae. North Amer. Flora 24:201-250.

Sargent, C.S. 1892. The silva of North America: A description of the trees which grow naturally in North America exclusive of Mexico. Houghton, Mifflin, Boston, Mass.

Seasteat, T.R., D.A. Crossley, Jr., and W.W. Hargrove. 1983. The effects of low-level consumption by canopy arthropods on growth and nutrient dynamics of black locust and red maple trees in the Southern Appalachians. Ecology 64:1040-1048.

Shukla, N.K., K.R. Singh, and R.S. Singh. 1986. A note on the physical and mechanical properties of Robinia pseudoacacia, Fraxinus spp., and Alianthus from Srinagar. (J\&K). Indian For. 112:139-150.

Small, J.K. 1933. Fabaceae, p. 669-743. In: Manual of southeastern flora. J.K. Small, New York.

Smith, A. 1992. Chemistry of the extractives of the black locust tree, p. 208-217. In: J. Hanover, K. Miller, and S. Plesko (eds.). Proc. Intl. Conf. on Black Locust: Biology, Culture, and Utilization, East Lansing, Mich., 17-21 June 1991.

Tingxiu, D. and L. Guofan. 1988. A regression model of the relationship between locust seedling growth and soil conditios. Plant and Soil 109:1722.

USDA Forest Service. 1974. The seeds of woody plants in the United States. USDA For. Serv. Agr. Hdbk. 450. U.S. Govt. Printing Office, Wash. D.C.

USDA Agric. Res. Ser. 1990. USDA plant hardiness zone map. Misc. Publ. 1475. USDA Agr. Res. Ser., Wash. D.C.

Vadas, J. 1911. Az Akac Monografiaja (The Monograph of Black Locust). Patria, Budapest, Czechoslovakia.

Vines, R.A. 1960. Trees, shrubs, and woody vines of the Southwest. Univ. Texas Press, Austin, Texas.

Vogel, C.S. and J.O. Dawson. 1993. Changes in tissue nitrogen and phosphorus and foliar free amino acids in autumn olive, black locust, american sycamore, and honey locust during autumn. Can J. For. Res. 23:665-672.

Wagner, M.R., R.E. Larson, and T.P. Craig. 1992. Ecology and silvics of New Mexico locust, Robinia neomexicana, with an emphasis on the arboreal form, p. 53-57. In: J. Hanover, K. Miller, and S. Plesko (eds.). Proc. Intl. Conf. on Black Locust: Biology, Culture, and Utilization, East Lansing, Mich., 17-21 June 1991.

Wandell, W.N. 1989. Handbook of landscape cultivars. East Prairie Publ. Co., Gladstone, Ill.

Wilson, J.K. 1944. Immersing seeds of species of Robinia in boiling water hastens germination. J. For. 42:453-454. 